\title{
GMR
}

\section{Discovery and characterization of a first set of polymorphic microsatellite markers in Siganus oramin}

\author{
Y.-X. Liu' ${ }^{1,2}$, C.-Y. Ma' ${ }^{1}$, H.-Y. Ma', C.-L. Feng ${ }^{1}$, S.-J. Li' ${ }^{1}$ and L.-B. Ma ${ }^{1}$ \\ ${ }^{1}$ Key Laboratory of East China Sea and Oceanic Fishery Resources Exploitation, \\ Ministry of Agriculture, East China Sea Fisheries Research Institute, \\ Chinese Academy of Fishery Sciences, Shanghai, China \\ ${ }^{2}$ College of Fisheries and Life Science, Shanghai Ocean University, \\ Shanghai, China \\ Corresponding authors: C.-Y. Ma / L.-B. Ma \\ E-mail: mcy0527@yahoo.com.cn / malingbo@vip.sina.com
}

Genet. Mol. Res. 14 (4): 15320-15324 (2015)

Received February 3, 2015

Accepted June 25, 2015

Published November 30, 2015

DOI http://dx.doi.org/10.4238/2015.November.30.8

ABSTRACT. Nine microsatellite DNA markers were developed and characterized for Siganus oramin by the $5^{\prime}$-anchored polymerase chain reaction technique. A total of 42 alleles were identified in 30 individuals, and the number of alleles per locus ranged from 3 to 7 , with an average of 4.7. The observed and expected heterozygosity per locus ranged from 0.5333 to 1.0000 and from 0.5254 to 0.8474 , respectively, with an average of 0.7422 and 0.6906 , respectively. A significant deviation from the HardyWeinberg equilibrium was detected at one microsatellite locus after a Bonferroni's correction $(P<0.0056)$. No significant linkage disequilibrium was found between any of the pairs of the nine loci. The microsatellite loci developed in this study will improve our understanding of the genetic background of $S$. oramin.

Key words: Siganus oramin; Microsatellite marker; Polymorphism 


\section{INTRODUCTION}

The rabbitfish (Siganus oramin) is a commercially important fish species, because of its great value as a food resource and in ecological conservation (Zhuang et al., 2008; Fang et al., 2009). It is widely distributed in the coral reefs of the Indo-Pacific region (Du et al., 2008), and the last few decades have seen a significant growth in rabbitfish cultivation in several regions (Lam, 1974). Previous studies on this species have mainly focused on its breeding biology, nutritional evaluation, and ecological monitoring (Wassef and Abdul Hady, 1997; Lai et al., 1999; Zhuang et al., 2008; Fang et al., 2009), but studies on the population genetic diversity and variation of this species are few in number.

Microsatellite markers, also known as simple sequence repeats (SSRs), are co-dominantly inherited, multi-allelic, highly informative, and abundantly distributed throughout the whole genome (Tautz and Renz, 1984; Tautz, 1989; Wright, 1993). Microsatellite markers have consequently become the favored marker in the last few years for genetic studies in fish (O'Connell and Wright, 1997); however, few microsatellite markers have been reported for this important fish species, which has hindered the evaluation of its population genetic structure.

Several strategies have been devised for microsatellite marker isolation (Zane et al., 2002), amongst which the 5 '-anchored polymerase chain reaction (PCR) technique is considered to be a rapid and economical protocol (Fisher et al., 1996). In this study, we developed nine polymorphic microsatellite markers from the genomic DNA of S. oramin, based on the 5'-anchored PCR method. This set of microsatellite markers will facilitate studies on the genetic differentiation and structure of S. oramin and its closely related species.

\section{MATERIAL AND METHODS}

\section{Sample collection and DNA extraction}

A total of 30 individuals of $S$. oramin were collected from Fujian Province, China. Genomic DNA was isolated from muscle tissue using a traditional phenol-chloroform extraction protocol, as described by Ma et al. (2010a).

\section{5'-anchored primer design and isolation of microsatellite markers}

Three $5^{\prime}$-anchored primers with the sequences $\operatorname{KKDBDBD}(\mathrm{AC})_{6}, \operatorname{KKVRVRV}(\mathrm{CT})_{6}$, and $\operatorname{KKRVRVR}(\mathrm{GT})_{6}$ were designed for microsatellite isolation, where $K=\mathrm{G} / \mathrm{T}, D=\mathrm{G} / \mathrm{A} / \mathrm{T}, B=\mathrm{G} / \mathrm{T} / \mathrm{C}$, $H=\mathrm{A} / \mathrm{C} / \mathrm{T}, V=\mathrm{A} / \mathrm{C} / \mathrm{G}$, and $R=\mathrm{A} / \mathrm{G}$. The primers were synthesized by Sangon Biotech Co. Ltd. (Shanghai, China).

PCR amplification was performed in a $25-\mu \mathrm{L}$ reaction volume containing $10 \mathrm{XPCR}$ buffer, 2.0 $\mathrm{mM} \mathrm{MgCl}, 0.2 \mathrm{mM}$ dNTP mix, $0.2 \mu \mathrm{M}$ of each primer, $1 \mathrm{U}$ Taq DNA polymerase, and approximately $100 \mathrm{ng}$ template DNA. The thermocycler conditions were as follows: an initial denaturation for 5 min at $94^{\circ} \mathrm{C}$, followed by 35 cycles of $45 \mathrm{~s}$ at $94^{\circ} \mathrm{C}, 45 \mathrm{~s}$ at annealing temperature, and $45 \mathrm{~s}$ at $72^{\circ} \mathrm{C}$, and a final extra extension at $72^{\circ} \mathrm{C}$ for $5 \mathrm{~min}$. The amplification products were separated on $1.5 \%$ agarose gels (TaKaRa, China). The amplified DNA fragments ranged from 200 to 750 bp in size, and were reclaimed and ligated with a pMD19-T vector (TaKaRa). They were then transformed into Escherichia coli DH5a cells (Tiangen Biotech Co. Ltd., China). The positive clones were identified by PCR with vector-specific primers, before being selected for sequencing using an $\mathrm{ABI} 3730 \mathrm{xl}$ sequencer (Applied Biosystems). 
The sequences were searched for microsatellites using the SSRHUNTER software (version1.3) (Li and Wan, 2005), and the microsatellite primers were designed using the Primer Premier 5.0 software (http://www.premierbiosoft.com/primerdesign/).

\section{Polymorphism characteristics and assessment}

Microsatellite loci polymorphisms were investigated in 30 individuals of S. oramin. PCR amplification was performed in a $25-\mu \mathrm{L}$ total volume containing 10X PCR buffer, $0.4 \mu \mathrm{M}$ of each primer, $0.2 \mathrm{mM}$ dNTP mix, $1 \cup$ Taq polymerase (TaKaRa), and approximately $100 \mathrm{ng}$ template DNA. After 5 min denaturation at $94^{\circ} \mathrm{C}$, amplification proceeded for 35 cycles $\left(94^{\circ} \mathrm{C}\right.$ for $30 \mathrm{~s}$, annealing temperature for each pair of primers (Table 1) for $40 \mathrm{~s}$, and $72^{\circ} \mathrm{C}$ for $45 \mathrm{~s}$ ), and a final extension for 5 min at $72^{\circ} \mathrm{C}$. The PCR products were separated on a $6 \%$ denaturing polyacrylamide gel and visualized by silver staining. The ranges of allele size were determined by referring to the $\mathrm{pBR} 322 / \mathrm{Mspl}$ marker (Tiangen Biotech). All of the methods used for the data analysis were as described by Ma et al. (2010b).

Table 1. Locus name, repeat sequence, primer sequence, annealing temperature (Ta), number of observed alleles $\left(N_{\mathrm{A}}\right)$, locus size, observed $\left(H_{\mathrm{O}}\right)$ and expected heterozygosity $\left(H_{\mathrm{E}}\right)$, and GenBank accession No. for nine polymorphic microsatellite loci in Siganus oramin.

\begin{tabular}{|c|c|c|c|c|c|c|c|}
\hline Locus (GenBank accession No.) & Repeat motif & Primer sequence $\left(5^{\prime}-3^{\prime}\right)$ & $\mathrm{Ta}\left({ }^{\circ} \mathrm{C}\right)$ & $N_{\mathrm{A}}$ & $\begin{array}{l}\text { Expected } \\
\text { size }(b p)\end{array}$ & $H_{\mathrm{O}}$ & $H_{\mathrm{E}}$ \\
\hline $\begin{array}{l}\text { Sigo1 (KM246735) } \\
\quad \text { (KJ655521-KJ655529) }\end{array}$ & $(\mathrm{CA})_{19}$ & $\begin{array}{l}\text { F: ACTGTGAGGAAGCCTTGGTTAA } \\
\text { R: TGTGCGTCTTTGTGTATGTTGT }\end{array}$ & 53 & 5 & 124 & 0.8000 & 0.7972 \\
\hline Sigo2 (KM246736) & $(\mathrm{TG})_{9}$ & $\begin{array}{l}\text { F: ACAAGAAGGTTAGAAAGACGGC } \\
\text { R: TTAAAGGCAAATGTTTGGAAAT }\end{array}$ & 48 & 4 & 222 & 0.6000 & 0.5254 \\
\hline Sigo3 (KM246737) & $(\mathrm{TG})_{16}$ & $\begin{array}{l}\text { F: TGTGCGTCTTTGTGTATGTTGT } \\
\text { R: ACTGTGAGGAAGCCTTGGTTAA }\end{array}$ & 53 & 7 & 124 & 0.9667 & 0.8379 \\
\hline Sigo4 (KM246738) & $(\mathrm{CA})_{17}$ & $\begin{array}{l}\text { F: ACTGTGAGGAAGCCTTGGTTAA } \\
\text { R: TGTGCGTCTTTGTGTATGTTGT }\end{array}$ & 53 & 6 & 120 & $1.0000^{*}$ & 0.8474 \\
\hline Sigo5 (KM246739) & $(\mathrm{TCC})_{6}$ & $\begin{array}{l}\text { F: GCAGAATGCCTTCGCCCCTC } \\
\text { R: CCGTGCTTCGCCACAGTAACA }\end{array}$ & 59 & 5 & 235 & 0.6786 & 0.7552 \\
\hline Sigo6 (KM246740) & $(\mathrm{CTG})_{9}$ & $\begin{array}{l}\text { F: TAAAAGCATAGGAAAGAAAAAGA } \\
\text { R: CCAAGTCACGACAAGACAAAATA }\end{array}$ & 49 & 5 & 189 & 0.5333 & 0.6299 \\
\hline Sigo7 (KM246741) & $(\mathrm{CT})_{7} \mathrm{CC}(\mathrm{CT})_{4}$ & $\begin{array}{l}\text { F: TCTCGCCTTGTTTCCCTGTTC } \\
\text { R: TGTCTGCACCCTGTTGCATGT }\end{array}$ & 55 & 3 & 115 & 0.8667 & 0.6198 \\
\hline Sigo8 (KM246742) & $(\mathrm{CA})_{37}$ & $\begin{array}{l}\text { F: CCCTCTCTTTAACATACCCACA } \\
\text { R: GACCACATCTTTCCAGCTCTAC }\end{array}$ & 55 & 3 & 222 & 0.5556 & 0.5737 \\
\hline Sigo9 (KM246743) & $(\mathrm{AC})_{8}$ & $\begin{array}{l}\text { F: TGTCCTACCTCGTATTCTTGGC } \\
\text { R: CTTCACTGACCGTTTTCTGTT }\end{array}$ & 54 & 4 & 164 & 0.6786 & 0.6292 \\
\hline
\end{tabular}

*Significant deviation from the Hardy-Weinberg equilibrium after a Bonferroni's correction $(P<0.0056)$.

\section{Data analysis}

The observed number of alleles $\left(N_{\mathrm{A}}\right)$, observed heterozygosity $\left(H_{\mathrm{O}}\right)$, expected heterozygosity $\left(H_{E}\right)$, polymorphism information content, chi-square tests for the Hardy-Weinberg equilibrium (HWE), and the linkage disequilibrium (LD) were calculated using POPGENE (version 1.31) (Yeh et al., 1997). Significance values for all multiple tests were corrected through a sequential Bonferroni procedure (Rice, 1989). MICRO-CHECKER was used to evaluate genotyping errors, the presence of null alleles, and allelic dropout (Van Oosterhout et al., 2004).

\section{RESULTS AND DISCUSSION}

High variability and relative ease of scoring are the two main features that make 
microsatellites very powerful markers for genetic studies. However, a major disadvantage of microsatellites is the high cost of their development. In this study, the discovery process was relatively easy, since the genomic background was not required. In addition, the screening effort was greatly reduced by the construction of genomic libraries enriched for $(A C)_{6},(C T)_{6}$, and $(G T)_{6}$ repeats. PCR profiles from genomic DNA with primers containing microsatellite repeats were employed, in order to capture the polymorphisms associated with microsatellite loci. This strategy is highly suitable for non-model species whose genomic information is frequently unknown. A sequencing analysis of 113 clones from the genomic libraries yielded 82 clones that contained microsatellite marker loci. Based on sequences with sufficient flanking regions, 31 pairs of primers were successfully designed using the Primer Premier 5.0 software. The polymorphisms of these loci were assessed using 30 individuals of $S$. oramin from Fujian Province, China.

As a result, nine pairs of primers amplified specific and polymorphic PCR products, and a total of 42 alleles were identified in the 30 individuals. $N_{A}$ per locus ranged from 3 to 7 , with an average of 4.7. The $H_{\mathrm{O}}$ and $H_{\mathrm{E}}$ per locus ranged from 0.5333 to 1.0000 and from 0.5254 to 0.8474 , respectively, with an average of 0.7422 and 0.6906 , respectively. One microsatellite locus (Sigo4) significantly deviated from the HWE after a Bonferroni's correction $(P<0.0056)$, which may have been due to the small sample size or the presence of null alleles. MICRO-CHECKER analysis showed no evidence of scoring errors, or technical or statistical artifacts. There was no significant genotypic LD between any of the pairs of the nine loci after a Bonferroni's correction ( $P>0.0056)$. These nine sequences were further searched in GenBank using the BLASTn program, and similar sequences were not found. The characteristics of these primers are listed in Table 1.

In conclusion, nine polymorphic microsatellite markers were developed for S. oramin using the 5 '-anchored PCR technique. These microsatellite primers are the first batch to be published for $S$. oramin, and will provide a valuable tool for studies on the genetic differentiation, structure, and effective management of $S$. oramin.

\section{ACKNOWLEDGMENTS}

Research supported by the National Science and Technology Support Plan (\#2013BAD13B04), the National Non-Profit Institutes (East China Sea Fisheries Research Institute) (\#2012T04), and the National Infrastructure of Fishery Germplasm Resources.

\section{REFERENCES}

Du YB, Li YY, Zhen YJ, Hu CB, et al. (2008). Toxic effects in Siganus oramin by dietary exposure to 4-tert-octylphenol. Bull. Environ. Contam. Toxicol. 80: 534-538.

Fang JKH, Wu RSS, Zheng GJ, Au DWT, et al. (2009). The use of muscle burden in rabbitfish Siganus oramin for monitoring polycyclic aromatic hydrocarbons and polychlorinated biphenyls in Victoria Harbour, Hong Kong and potential human health risk. Sci. Tot. Environ. 407: 4327-4332.

Fisher PJ, Gardner RC and Richardson TE (1996). Single locus microsatellites isolated using 5' anchored PCR. Nucleic Acids Res. 24: 4369-4371.

Lai MS, Cheung RYH and Chan KM (1999). Metal concentrations in tissues of rabbitfish (Siganus oramin) collected from Tolo Harbour and Victoria Harbour in Hong Kong. Mar. Pollut. Bull. 39: 234-238.

Lam TJ (1974). Siganids: Their biology and mariculture potential. Aquaculture 3: 325-354.

Li Q and Wan J (2005). SSRhunter: Development of a local searching software for SSR sites. Yi Chuan 27: 808-810.

Ma C, Cheng Q, Zhang Q, Zhuang P, et al. (2010a). Genetic variation of Coilia ectenes (Clupeiformes: Engraulidae) revealed by the complete cytochrome $b$ sequences of mitochondrial DNA. J. Exp. Mar. Biol. Ecol. 385: 14-19.

Ma H, Ma C, Ma L and Cui H (2010b). Novel polymorphic microsatellite markers in Scylla paramamosain and cross-species 
amplification in related crab species. J. Crustacean Biol. 30: 441-444.

O'Connell M and Wright J (1997). Microsatellite DNA in fishes. Rev. Fish Biol. Fisher. 7: 331-363.

Rice WR (1989). Analyzing tables of statistical tests. Evolution 43: 223-225.

Tautz D (1989). Hypervariability of simple sequences as a general source for polymorphic DNA markers. Nucleic Acids Res. 17: 6463-6471.

Tautz D and Renz M (1984). Simple sequences are ubiquitous repetitive components of eukaryotic genomes. Nucleic Acids Res. 12: 4127-4138.

Van Oosterhout C, Hutchinson WF, Wills DPM and Shipley P (2004). MICRO-CHECKER: software for identifying and correcting genotyping errors in microsatellite data. Mol. Ecol. Notes 4: 535-538.

Wassef EA and Abdul Hady HA (1997). Breeding biology of rabbitfish Siganus canaliculatus (Siganidae) in mid Arabian Gulf. Fish. Res. 33: 159-166.

Wright JM (1993). DNA fingerprinting of fishes. Biochem. Mol. Biol. Fish. 2: 57-91.

Yeh FC, Yang RC, Boyle TB, Ye Z, et al. (1997). POPGENE, the user-friendly shareware for population genetic analysis. University of Alberta and the Centre for International Forestry Research. Available at [www.ualberta.ca/ fyeh/].

Zane L, Bargelloni L and Patarnello T (2002). Strategies for microsatellite isolation: A review. Mol. Ecol. 11: 1-16.

Zhuang P, Song C, Zhang L, Zhang T, et al. (2008). Evaluation of nutritive quality and nutrient components in the muscle of Siganus oramin. J. Fish. China 32: 77-83. 